\title{
Correction to: Late initiation of antiretroviral therapy: inequalities by educational level despite universal access to care and treatment
}

Amanda Rodrigues ${ }^{1}$, Claudio J. Struchiner ${ }^{2}$, Lara E. Coelho ${ }^{3}$, Valdilea G. Veloso ${ }^{3}$, Beatriz Grinsztejn ${ }^{3}$ and Paula M. Luz ${ }^{3^{*}}$

\section{Correction to: BMC Public Health 21, 389 (2021) https://doi.org/10.1186/s12889-021-10421-8}

It was highlighted that in the original article [1] the Acknowledgments section was incorrect. This Correction article shows the incorrect and correct Acknowledgments section. The original article has been updated.

\section{Incorrect}

Acknowledgements

Not applicable.

\section{Correct}

Acknowledgements

This study was financed in part by the Coordination for the Improvement of Higher Education Personnel (Coordenação de Aperfeiçoamento de Pessoal de Nível Superior [CAPES]), finance Code 001.

\section{Author details}

'Escola Nacional de Saúde Pública, Fundação Oswaldo Cruz, Rio de Janeiro,

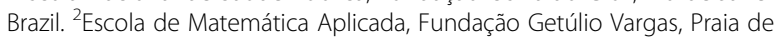
Botafogo, 190, Rio de Janeiro, Brazil. ${ }^{3}$ Instituto Nacional de Infectologia Evandro Chagas, Fundação Oswaldo Cruz, Av. Brasil 4365, Manguinhos, Rio de Janeiro 21040-900, Brazil.
Published online: 01 April 2021

\section{Reference}

1. Rodrigues, et al. Late initiation of antiretroviral therapy: inequalities by educational level despite universal access to care and treatment. BMC Public Health. 2021;21:389. https://doi.org/10.1186/s12889-021-10421-8.

The original article can be found online at https://doi.org/10.1186/s12889021-10421-8.

* Correspondence: luzpaulamendes@gmail.com

${ }^{3}$ Instituto Nacional de Infectologia Evandro Chagas, Fundação Oswaldo Cruz, Av. Brasil 4365, Manguinhos, Rio de Janeiro 21040-900, Brazil

Full list of author information is available at the end of the article

C C The Author(s). 2021 Open Access This article is licensed under a Creative Commons Attribution 4.0 International License, which permits use, sharing, adaptation, distribution and reproduction in any medium or format, as long as you give appropriate credit to the original author(s) and the source, provide a link to the Creative Commons licence, and indicate if changes were made. The images or other third party material in this article are included in the article's Creative Commons licence, unless indicated otherwise in a credit line to the material. If material is not included in the article's Creative Commons licence and your intended use is not permitted by statutory regulation or exceeds the permitted use, you will need to obtain permission directly from the copyright holder. To view a copy of this licence, visit http://creativecommons.org/licenses/by/4.0/ The Creative Commons Public Domain Dedication waiver (http://creativecommons.org/publicdomain/zero/1.0/) applies to the data made available in this article, unless otherwise stated in a credit line to the data. 